\title{
Water-soluble Antioxidant Potential of Turkish Pepper Cultivars
}

\author{
Anne Frary ${ }^{1,4}$, M. Ali Keçeli², Bilal Ökmen², Hasan Ö. Şığva ${ }^{2}$, \\ Ahmet Yemenicioğlu ${ }^{3}$, and Sami Doğanlar ${ }^{1}$ \\ Department of Biology, Izmir Institute of Technology, Faculty of Science, \\ Gulbahce, Izmir 35430, Turkey
}

Additional index words. Capsicum annuum, water-soluble antioxidant capacity, phenolics, vitamin $\mathrm{C}$, ascorbic acid, nutrition

\begin{abstract}
In this work, 29 pepper cultivars that represent the diversity of types and varieties grown in Turkey were analyzed for water-soluble antioxidant capacity and phenolic and vitamin $C$ contents. In addition, 14 non-Turkish cultivars were tested for comparison. Significant diversity was observed in the different cultivars with the most variation (7.4-fold) seen for total antioxidant capacity, which ranged from 2.57 to 18.96 mmol Trolox/kg. Vitamin C content for the peppers ranged from 522 to $1631 \mathrm{mg} \cdot \mathrm{kg}^{-1}$, a 3.1-fold difference, whereas total phenolic content for the pepper cultivars ranged from 607 to $2724 \mathrm{mg} \cdot \mathrm{kg}^{-1}$, a 4.5 -fold difference. When cultivars were grouped by morphology/ use, it was found that some types had significantly more variation and higher antioxidant activities than other types. Thus, for water-soluble antioxidant capacity, most variation was seen in long, blunt-ended Çarliston types, whereas long, pointed Sivri peppers had the highest mean capacity. Bell-shaped Dolmalık and Sivri peppers had the most variation for phenolic content, but fancy Süs and Sivri types had the highest means for this trait. Dolmalık types showed the most variation for vitamin $C$ content, whereas Süs and Sivri peppers had the highest means for this character. All three parameters were significantly and positively correlated with the strongest correlation between total antioxidant capacity and phenolic content $(r=0.71)$. The presence of significant variation for antioxidant content in Turkish germplasm indicates that this material can be used for improvement and genetic mapping of nutritional content in pepper.
\end{abstract}

Based on the American Dietetic Association definition (Bloch and Thomson, 1995), pepper (Capsicum annuum) can be considered a functional food because it contains high levels of certain compounds that have beneficial effects for humans. Pepper contains vitamins $\mathrm{A}, \mathrm{B}, \mathrm{C}$, and $\mathrm{E}$ and phytochemicals such as phenolic compounds, carotenoids, and capsaicin (USDA Nutrient Data Laboratory, 2007). These compounds are reported to have a multitude of favorable effects for humans, including antioxidant, anticarcinogenic, antimutagenic, antiaging, and antibacterial properties (Chu et al., 2002; Ferrari and Torres, 2003; Surh and Seoul, 2002). Antioxidants are of particular interest because they reduce free radicals and reactive oxygen species (ROS). ROS and other free radicals are generated as

Received for publication 30 July 2007. Accepted for publication 19 Nov. 2007.

This research was funded by grants from The Scientific and Technological Research Council of Turkey (TÜBITAK Project No. TOGTAG-3163), the Republic of Turkey Prime Ministry State Planning Organization (DPT Project No. 2002K120690), and Izmir Institute of Technology (IYTE 2002-29). We thank the Aegean Agricultural Research Institute, Atatürk Central Horticultural Research Institute, and the Center for Genetic Resources, The Netherlands, for providing seeds.

${ }^{1}$ Department of Biology

${ }^{2}$ Biotechnology Program

${ }^{3}$ Department of Food Engineering

${ }^{4}$ To whom reprint requests should be addressed; e-mail annefrary@iyte.edu.tr part of normal cellular metabolism and in response to environmental factors such as ultraviolet irradiation (Halliwell, 2006). Accumulation of these highly reactive molecules in cells can damage cellular components, including lipids, membranes, nucleic acids, and proteins. This oxidative stress directly or indirectly results in many human diseases such as cardiovascular disease and cancer (Percival, 1998). In addition to their role in defense against human diseases, antioxidants have an important role in plants' defense system and are produced in response to both biotic and abiotic stresses, which generate ROS in plants (Sakihama et al., 2002; Slater et al., 2003).

One commonly used approach for determining antioxidant capacity of plant extracts is measurement of the total hydrophilic or lipophilic antioxidant capacity of the extract (Cao et al., 1996; Chu et al., 2002; Halvorsen et al., 2002; Ou et al., 2002; Pellegrini et al., 2003). This allows detection of all water or lipid-soluble antioxidants in the extract and takes into account any synergistic effects between individual antioxidants. Alternatively, individual antioxidants can be extracted and characterized. For example, vitamin $\mathrm{C}$ is a water-soluble antioxidant that neutralizes superoxide, hydrogen peroxide, and hydroxyl radical (Podsedek, 2007). Vitamin C also reduces tocopheroxyl radicals to regenerate the antioxidant form of vitamin E (Davey et al., 2000). Phenolic compounds are the largest category of phytochemicals and include flavonoids, phenolic acids, and phenols. These compounds are water-soluble and are excel- lent antioxidants because their structure allows them to easily donate hydrogen molecules to free radicals (Podsedek, 2007). Lipophilic antioxidants include compounds such as vitamin E, carotenoids, and conjugated phenolics (Podsedek, 2007).

Recent surveys of commonly consumed vegetables indicated that both red and green peppers have high levels of total antioxidant capacity as compared with other crops. In three separate studies, pepper ranked first with higher total antioxidant capacity (determined by summing the values for hydrophilic and lipophilic antioxidant fractions) than other vegetables such as broccoli, carrot, spinach, and kale (Chu et al., 2002; Halvorsen et al., 2002; Ou et al., 2002). Other researchers found that pepper antioxidant capacity was only exceeded by that of spinach (Pellegrini et al., 2003). In addition to high total antioxidant capacity, pepper was found to be a good source of phenolic compounds, ranking fourth in total phenolic content after broccoli, spinach, and onion (Chu et al., 2002). In addition to their antioxidant role, phenolic compounds contribute to fruit color, flavor, and pungency (Estrada et al., 2002).

In the past, plant breeders focused on agronomically important traits such as yield and disease resistance. However, with increased demand from informed consumers for more nutritional and diverse fruits and vegetables, breeders are turning their attention to traits such as improved phytochemical content. Improvement of these traits by breeding is difficult because of their polygenic nature. However, if the genes controlling the character of interest are identified and localized, molecular breeding techniques (i.e., marker-assisted selection) can be used for trait improvement. For breeding efforts to be successful, variation for the trait(s) must be present in the species of interest. Thus, a first step toward improving the antioxidant content of a crop like pepper is a systematic screen of germplasm for the trait(s). Numerous studies examined the total antioxidant, vitamin $\mathrm{C}$, and phenolic contents of pepper; however, these studies commonly used one or a few cultivars and examined the effects of factors such as maturity and growth/environmental conditions, including salinity and organic management (for example, Chassy et al., 2006; Deepa et al., 2007; Gnayfeed et al., 2001; Howard et al., 2000; Marin et al., 2004; Navarro et al., 2006). Fewer researchers analyzed these compounds in multiple pepper genotypes. Notable exceptions include the work of Deepa et al. (2006) and GuilGuerrero et al. (2006). In each of these studies, 10 C. annuum cultivars were examined for their nutrient composition, including total antioxidant activity and vitamin $\mathrm{C}$ and carotenoid contents. Antonious et al. (2006) also examined variability for antioxidants in pepper, including 17 accessions from four species: C. annuum, C. chinense, C. baccatum, and $C$. frutescens.

Turkey ranks second in worldwide pepper production with $1,745,000 \mathrm{t}$ produced in 2005 (Food and Agriculture Organization of 
the United Nations, 2005). Peppers are also an important part of Turkish cuisine and are consumed fresh, pickled, grilled, and stuffed as well as in salads and as a component of cooked dishes. In the present study, genotypic variation for antioxidants in pepper was studied by analyzing total water-soluble antioxidant capacity, phenolic content, and vitamin $\mathrm{C}$ content in 43 pepper cultivars, including 29 Turkish accessions. Fourteen non-Turkish cultivars grown in Turkey or worldwide were also analyzed. These foreign cultivars included standard, widely grown varieties such as 'California Wonder' and 'Yolo Wonder'. Only water-soluble antioxidant capacity was measured because previous studies indicated that, compared with hydrophilic antioxidants, lipophilic antioxidants contribute very little to the total antioxidant capacity of pepper. For example, $\mathrm{Wu}$ et al. (2004) found that antioxidant capacity of the lipophilic fraction represented only $4.6 \%$ of the total antioxidant capacity. Similarly, Navarro et al. (2006) found that the antioxidant capacity of the lipophilic fraction of green fruits was less than $1 \%$ of that for the hydrophilic fraction. Significant genetic diversity was detected in the water-soluble antioxidant capacities and components of the tested pepper accessions and candidate lines were identified for future breeding programs. Breeding of higher antioxidant pepper cultivars could help improve human health because a diet rich in fruits and vegetables is considered to be the most important protection against many types of diseases (Ferrari and Torres, 2003).

\section{Materials and Methods}

Plant material. Seeds for the Turkish cultivars were obtained from the Turkish National Germplasm Collection at the Aegean Agricultural Research Institute (AARI, Izmir, Turkey) and from the Atatürk Central Horticultural Research Institute (Yalova, Turkey). Seeds for the other cultivars were obtained from the Center for Genetic Resources, The Netherlands, and from seed distributors in Turkey and the United States (Table 1). Seeds were planted in a climate-controlled greenhouse in Apr. 2006 and three to five replicate plants were grown for each accession. Although some cultivars are consumed when they are red, to standardize the results, all fruits were harvested at the mature green stage in July and August and samples were stored at $-20{ }^{\circ} \mathrm{C}$ until assays were performed. All assays were completed within 1 month of harvest.

Determination of antioxidant capacity. For the extraction of antioxidants, a 150-g sample was taken from at least four individual peppers and was homogenized with 150 $\mathrm{mL}$ cold distilled water for $2 \mathrm{~min}$ at low speed in a Waring blender (Model HGB2WTS3; Waring Corp., Torrington, CT) equipped with a 1-L double-walled stainless steel jar chilled by circulating water at $4{ }^{\circ} \mathrm{C}$. The samples were deseeded before homogenization with the exception of two very small-

Table 1. Description of pepper cultivars used for antioxidant trait assays.

\begin{tabular}{|c|c|c|c|c|c|}
\hline Cultivar (origin) & $\begin{array}{l}\text { Accession number } \\
\left(\text { source }^{z}\right)\end{array}$ & $\begin{array}{l}\text { Country of } \\
\text { origin }\end{array}$ & Type & Pungency & Color $^{\mathrm{y}}$ \\
\hline 333 Biber & $\mathrm{NA}^{\mathrm{x}}(1)$ & Turkey & Çarliston & Sweet & Yellow \\
\hline Acı Biber (Gaziantep) & TR47780 (1) & Turkey & Dolmalık & Hot & Green \\
\hline Acı Sivri Biber (Bursa) & TR66271 (1) & Turkey & Sivri & Hot & Green \\
\hline Apollo F1 & NA (2) & Hungary & Dolmalık & Sweet & Yellow \\
\hline Arnavut Biber & TR66272 (1) & Turkey & Süs & Hot & Green \\
\hline Arnavut Biber, sivri & TR66299 (1) & Turkey & Süs & Hot & Green \\
\hline Ayaş & NA (1) & Turkey & Sivri & Sweet & Green \\
\hline California Wonder & NA (3) & USA & Dolmalık & Sweet & Green \\
\hline Çarliston Biber (Bursa) & TR66275 (1) & Turkey & Çarliston & Sweet & Yellow \\
\hline Carolina Wonder & NA (2) & USA & Dolmalık & Sweet & Green \\
\hline Cecil RZ F1 & NA (2) & Hungary & Dolmalık & Sweet & Yellow \\
\hline Charleston Belle & NA (2) & USA & Dolmalık & Sweet & Green \\
\hline Cherry Pick & NA (2) & USA & Süs & Sweet & Green \\
\hline Chile Negro & NA (3) & Mexico & Süs & Hot & Dark green \\
\hline Cuma Ovası & NA (1) & Turkey & Sivri & Hot & Light green \\
\hline Dolmalık & TR70630 (1) & Turkey & Dolmalık & Hot & Green \\
\hline Dolmalık Yeşil (Bursa) & TR66270 (1) & Turkey & Dolmalık & Sweet & Green \\
\hline Domat Biberi (Bursa) & TR66393 (1) & Turkey & Dolmalık & Hot & Light green \\
\hline Düğme Biber (Bursa) & TR66316 (1) & Turkey & Süs & Hot & Green \\
\hline Edison & NA (2) & Netherlands & Dolmalık & Sweet & Green \\
\hline Ege-91 & NA (1) & Turkey & Sivri & Sweet & Light green \\
\hline Farya & NA (2) & USA & Çarliston & Sweet & Yellow \\
\hline Fiesta & NA (2) & Netherlands & Dolmalık & Sweet & Green \\
\hline Finli Biber & TR66380 (1) & Turkey & Sivri & Hot & Light green \\
\hline Kale & NA (1) & Turkey & Dolmalık & Hot & Light green \\
\hline Kandil Dolma Biber & NA (1) & Turkey & Dolmalık & Sweet & Light green \\
\hline Menderes & NA (1) & Turkey & Sivri & Hot & Light green \\
\hline Raspires F1 & NA (2) & Hungary & Çarliston & Hot & Yellow \\
\hline Şahnalı Biber & NA (1) & Turkey & Sivri & Hot & Green \\
\hline Salçalık Biber & TR66259 (1) & Turkey & Salçalık & Sweet & Red \\
\hline Salçalık Biber (Bursa) & TR66389 (1) & Turkey & Salçalık & Sweet & Red \\
\hline Salçalık Biber (Gaziantep) & TR48614 (1) & Turkey & Salçalık & Sweet & Red \\
\hline Sera Demre & NA (1) & Turkey & Sivri & Sweet & Green \\
\hline Sweet Long Slim Red & NA (3) & USA & Sivri & Sweet & Red \\
\hline Tatlı Kıvırcık Biber & TR66305 (1) & Turkey & Sivri & Sweet & Light green \\
\hline Variegated Flash & NA (3) & USA & Süs & Hot & Purple \\
\hline Yağlık Biber & TR66378 (1) & Turkey & Salçalık & Sweet & Red \\
\hline Yağlık Biber (Bursa) & TR66384 (1) & Turkey & Salçalık & Sweet & Red \\
\hline Yalova Biber & NA (4) & Turkey & Sivri & Sweet & Yellow \\
\hline Yalova Çarliston 341 & NA (4) & Turkey & Çarliston & Sweet & Yellow \\
\hline Yalova Tatlı Sivri Biber & NA (4) & Turkey & Sivri & Sweet & Light green \\
\hline Yalova Yağlık & NA (4) & Turkey & Salçalık & Sweet & Red \\
\hline Yolo Wonder 31-22 & NA (3) & USA & Dolmalık & Sweet & Green \\
\hline
\end{tabular}

$\mathrm{z} 1$ = Aegean Agricultural Research Institute, İzmir, Turkey; 2 = purchased from Turkish or U.S. distributor; 3 = Center for Genetic Resources, The Netherlands; 4 = Atatürk Central Horticultural Research Institute, Yalova, Turkey.

${ }^{y}$ Color of fruits at normal stage of consumption.

${ }^{\mathrm{N}} \mathrm{NA}=$ no accession number.

sized peppers ('Arnavut Biber' and 'Variegated Flash'), which are consumed with seeds. For cultivars with small fruits, a $50-\mathrm{g}$ sample was homogenized with $50 \mathrm{~mL}$ distilled water using a $200-\mathrm{mL}$ jar and the same homogenization conditions. A 20 -g sample of fruit pulp was then filtered through four layers of cheesecloth. The filtrate was further clarified by centrifugation at $3000 \times g$ for 10 min at $4{ }^{\circ} \mathrm{C}$. The clear supernatant was used for the determination of antioxidant capacity according to the method of Re et al. (1999). In this method, ABTS [2,2' -azinobis-(3ethyl-benzothiazoline-6-sulfonic acid)] radical cation decolorization caused by the test samples was monitored by spectrophotometer (Model 1700; Shimadzu, Kyoto, Japan) at $734 \mathrm{~nm}$. The reaction mixture contained $2 \mathrm{~mL}$ potassium persulfate oxidized ABTS radical solution in phosphate-buffered saline at $\mathrm{pH} 7.4$ and $2.5,5$. or $7.5 \mu \mathrm{L}$ of extract [or $20 \mu \mathrm{L}$ of Trolox $(0.0045-0.03 \mu \mathrm{mol}$ in reaction mixture) to prepare the standard curves]. The decrease in absorbance of each sample was monitored for $6 \mathrm{~min}$ and tests were conducted three times at each sample volume for each supernatant. Percent inhibitions at 1,3, and 6 min were then plotted against sample volume. The slope for each line $(1,3$, and $6 \mathrm{~min})$, which indicated the percent inhibition of the sample per microliter, was determined and graphed against time using KaleidaGraph (Synergy Software, Reading, PA). This software was also used to calculate the area under the curve (AUC). This value and the AUC for the Trolox standard curve were used to calculate antioxidant capacity values, which were expressed as $\mathrm{mmol}$ Trolox/kg fresh weight (FW) of peppers.

Determination of total phenolic content. For determination of total phenolic content, homogenates were prepared as described for antioxidant capacity determination. After 
centrifugation, the clear supernatant was used for the determination of total phenolic content according to the method of Singleton and Rossi (1965) using Folin-Ciocalteu as the reactive reagent and gallic acid as the standard. Briefly, $2 \mathrm{~mL}$ of sample extract was mixed with $10 \mathrm{~mL} 2 \mathrm{~N}(10 \%)$ Folin-Ciocalteu's reagent. After $3 \mathrm{~min}, 8 \mathrm{~mL} 0.7 \mathrm{~m}$ sodium carbonate was added. The reaction mixture was incubated for $2 \mathrm{~h}$ at room temperature and absorbance measured at $765 \mathrm{~nm}$ in a spectrophotometer. Three replicates were measured for each supernatant sample. The results were expressed as milligrams gallic acid equivalents $/ \mathrm{kg} \mathrm{FW}$ of peppers.

Determination of vitamin $C$ content. Vitamin $\mathrm{C}$ content was determined by the AOAC 967.21 titrimetric method (Augustin, 1994) using 2,6-dichloroindophenol as the reactive substance and L-(+)-ascorbic acid for calibration. The extractions were conducted by homogenization of $100 \mathrm{~g}$ peppers without seeds (taken from at least four individual fruit) with $115 \mathrm{~mL}$ acetic acid-metaphosphoric acid extraction solution for $2 \mathrm{~min}$ at low speed in a Waring blender at $4{ }^{\circ} \mathrm{C}$. A $35-\mathrm{g}$ sample of each homogenate was diluted with extraction solution to a final volume of 100 $\mathrm{mL}$. This dilution was filtered and used in titration. For each diluted pepper extract, the vitamin $\mathrm{C}$ content of three replicate samples was measured. The results were expressed as milligrams vitamin $\mathrm{C} / \mathrm{kg} \mathrm{FW}$ of peppers.

Statistical analyses. Total water-soluble antioxidant capacity, total phenolic content, and vitamin $\mathrm{C}$ content of the pepper fruits were analyzed using analysis of variance and Fisher's protected least significant difference. Analyses were performed across all cultivars and also across cultivars grouped by morphology/use type as explained in the "Results and Discussion."

\section{Results and Discussion}

The 43 pepper accessions analyzed in this work included both Turkish and non-Turkish cultivars (Table 1). Most (25 of 29) of the Turkish lines were obtained from the National Germplasm Collection at AARI representing the diversity of pepper accessions grown in the country. These lines included varieties such as 'Ayaş' and 'Kale', which are grown throughout Turkey as well as regional cultivars that are grown only in specific areas. An example of such a cultivar is the accession 'Acı Biber' (meaning literally, hot pepper) from Gaziantep in southeastern Anatolia, a region that is famous for its hot peppers. Also included were 14 non-Turkish varieties, including $F_{1}$ hybrids such as 'Apollo' and 'Cecil' that are grown in Turkey and standard cultivars that are grown throughout the world. For comparison, the peppers were classified into five groups based on their morphology or primary use. These classes were: bell-type (Dolmalı) peppers that are used for stuffing; long, pointed (Sivri) peppers and long, bluntended Charleston-type (Çarliston) peppers that are often consumed raw; small-fruited "fancy" (Süs) peppers that are eaten fresh or pickled; and paste (Salçalık) peppers that are processed into paste. However, these classes cannot be considered definitive because each pepper type is not used exclusively for only one purpose. For example, paste peppers can also be stuffed. Representative fruits of each type are shown in Figure 1. Most classes included both pungent (hot) and sweet pepper accessions with 15 hot and 28 sweet cultivars (Table 1).

Total water-soluble antioxidant capacity. Significant variation in total water-soluble antioxidant capacity was observed in the analyzed pepper cultivars. Values ranged from 2.57 to $18.96 \mathrm{mmol}$ Trolox $/ \mathrm{kg}$, a 7.4fold difference (Table 2). The five cultivars with highest antioxidant activities were all Turkish cultivars: Ege-91, Yalova Tatlı Sivri Biber, Domat Biberi, Finli Biber, and Ayaş.

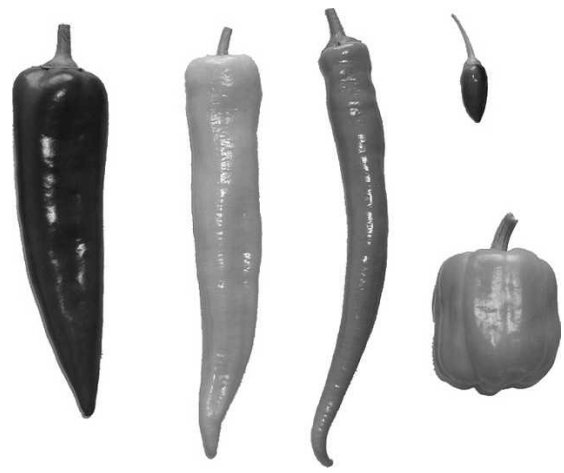

Fig. 1. Five types of peppers commonly grown in Turkey. From left to right, fruits of Salçalık, Çarliston, Sivri, Süs (top), and Dolmalık (bottom) -type cultivars.

Table 2. Antioxidant capacity, total phenolic content, and vitamin $\mathrm{C}$ content in pepper cultivars. ${ }^{\mathrm{z}}$

\begin{tabular}{|c|c|c|c|c|c|c|}
\hline Cultivar (location) & $\begin{array}{c}\text { Antioxidant } \\
\text { capacity (mmol } \\
\text { Trolox/kg) } \pm \text { SE }\end{array}$ & Rank & $\begin{array}{c}\text { Phenolic } \\
\text { content } \\
\left(\mathrm{mg} \cdot \mathrm{kg}^{-1}\right) \pm \mathrm{SE}\end{array}$ & Rank & $\begin{array}{c}\text { Vitamin } \mathrm{C} \\
\text { content } \\
\left(\mathrm{mg} \cdot \mathrm{kg}^{-1}\right) \pm \mathrm{SE}\end{array}$ & Rank \\
\hline Ege-91 & $18.96 \pm 0.24 \mathrm{a}^{\mathrm{y}}$ & 1 & $2,724 \pm 4.9 \mathrm{a}$ & 1 & $1,519 \pm 2.7 \mathrm{~b}$ & 2 \\
\hline Yalova Tatlı Sivri Biber & $17.65 \pm 0.25 \mathrm{~b}$ & 2 & $1,220 \pm 4.5$ no & 21 & $1,502 \pm 2.7 \mathrm{~b}$ & 4 \\
\hline Domat Biberi (Bursa) & $14.60 \pm 0.64 \mathrm{c}$ & 3 & $1,796 \pm 2.1 \mathrm{f}$ & 6 & $1,177 \pm 7.6 \mathrm{gh}$ & 12 \\
\hline Finli Biber & $13.40 \pm 0.12 \mathrm{~d}$ & 4 & $2,239 \pm 8.9 \mathrm{c}$ & 3 & $1,276 \pm 18.4 \mathrm{e}$ & 7 \\
\hline Ayaş & $12.67 \pm 0.10 \mathrm{e}$ & 5 & $1,730 \pm 3.7 \mathrm{~g}$ & 9 & $964 \pm 12.41$ & 21 \\
\hline Çarliston Biber (Bursa) & $12.64 \pm 0.11 \mathrm{e}$ & 6 & $1,782 \pm 19 \mathrm{f}$ & 8 & $1,140 \pm 48.1 \mathrm{i}$ & 15 \\
\hline Duğme Biber (Bursa) & $10.25 \pm 0.58 \mathrm{f}$ & 7 & $1,094 \pm 8.6 \mathrm{q}$ & 26 & $1,257 \pm 4.4$ ef & 8 \\
\hline Arnavut Biber, sivri & $9.99 \pm 0.15 \mathrm{fg}$ & 8 & $2,185 \pm 12.9 \mathrm{~d}$ & 4 & $1,098 \pm 8.5 \mathrm{j}$ & 16 \\
\hline Menderes & $9.88 \pm 0.06 \mathrm{fg}$ & 9 & $1,925 \pm 8.9 \mathrm{e}$ & 5 & $1,164 \pm 13.5 \mathrm{ghi}$ & 13 \\
\hline Arnavut Biber & $9.51 \pm 0.18 \mathrm{gh}$ & 10 & $1,440 \pm 12.4 \mathrm{k}$ & 15 & $1,631 \pm 9.7 \mathrm{a}$ & 1 \\
\hline Sera Demre & $9.46 \pm 0.11 \mathrm{gh}$ & 11 & $946 \pm 1.2 \mathrm{vw}$ & 35 & $926 \pm 4.4 \mathrm{mno}$ & 25 \\
\hline Variegated Flash & $9.13 \pm 0.26 \mathrm{hi}$ & 12 & $2,311 \pm 11.3 \mathrm{~b}$ & 2 & $\mathrm{ND}^{\mathrm{x}}$ & \\
\hline Cecil RZ F1 & $8.89 \pm 0.06 \mathrm{ij}$ & 13 & $988 \pm 7.5 \mathrm{u}$ & 33 & $522 \pm 4.7 \mathrm{w}$ & 42 \\
\hline Şahnali Biber & $8.81 \pm 0.16 \mathrm{ij}$ & 14 & $1,578 \pm 11.9 \mathrm{i}$ & 11 & $778 \pm 24.3 \mathrm{~s}$ & 32 \\
\hline Tatlı Kıvırcık Biber & $8.78 \pm 0.14 \mathrm{ij}$ & 15 & $1,394 \pm 4.51$ & 17 & $1,198 \pm 24.7 \mathrm{~g}$ & 10 \\
\hline Acı Sivri Biber (Bursa) & $8.59 \pm 0.14 \mathrm{j}$ & 16 & $1,476 \pm 7.5 \mathrm{j}$ & 13 & $1,376 \pm 11.6 \mathrm{~d}$ & 6 \\
\hline Chile Negro & $8.52 \pm 0.36 \mathrm{j}$ & 17 & $1,790 \pm 3.3 \mathrm{f}$ & 7 & $1,088 \pm 5.0 \mathrm{j}$ & 17 \\
\hline Yalova Biber & $8.37 \pm 0.13 \mathrm{j}$ & 18 & $1,691 \pm 10.6 \mathrm{~h}$ & 10 & $916 \pm 8.8$ nopq & 27 \\
\hline Cherry Pick & $7.52 \pm 0.10 \mathrm{k}$ & 19 & $1,482 \pm 9.8 \mathrm{j}$ & 12 & $1,436 \pm 20.0 \mathrm{c}^{1}$ & 5 \\
\hline Yolo Wonder 31-22 & $7.34 \pm 0.08 \mathrm{k}$ & 20 & $1,232 \pm 8.1 \mathrm{n}$ & 20 & $1,519 \pm 3.0 \mathrm{~b}$ & 3 \\
\hline Cuma Ovası & $6.99 \pm 0.08 \mathrm{k}$ & 21 & $1,440 \pm 13.8 \mathrm{k}$ & 14 & $943 \pm 6.1 \mathrm{lmn}$ & 23 \\
\hline Charleston Belle & $6.30 \pm 0.281$ & 22 & $756 \pm 9.8 \mathrm{z}$ & 41 & $778 \pm 6.1 \mathrm{~s}$ & 34 \\
\hline Apollo F1 & $6.11 \pm 0.09 \mathrm{~lm}$ & 23 & $1,110 \pm 9.7 \mathrm{pq}$ & 25 & $778 \pm 3.0 \mathrm{~s}$ & 33 \\
\hline California Wonder & $6.07 \pm 0.11 \mathrm{~lm}$ & 24 & $764 \pm 12.2 \mathrm{z}$ & 40 & $1,153 \pm 1.7 \mathrm{hi}$ & 14 \\
\hline Kandil Dolma Biber & $5.62 \pm 0.10 \mathrm{~m}$ & 25 & $896 \pm 13 x$ & 38 & $974 \pm 5.91$ & 20 \\
\hline Dolmalık & $5.62 \pm 0.04 \mathrm{mn}$ & 26 & $1,052 \pm 7.7 \mathrm{r}$ & 27 & $627 \pm 0.0 \mathrm{u}$ & 38 \\
\hline Acı Biber (Gaziantep) & $5.48 \pm 0.16$ no & 27 & $1,411 \pm 7.41$ & 16 & $1,234 \pm 22.9 \mathrm{f}$ & 9 \\
\hline Dolmalık Yeşil (Bursa) & $5.43 \pm 0.13$ no & 28 & $1,014 \pm 6.2 \mathrm{st}$ & 31 & $945 \pm 11.6 \mathrm{~lm}$ & 22 \\
\hline Raspires F1 & $5.31 \pm 0.07$ no & 29 & $1,233 \pm 11.9 \mathrm{n}$ & 19 & $939 \pm 4.5$ lmno & 24 \\
\hline $\begin{array}{l}\text { Salçalık Biber } \\
\text { (Gaziantep) }\end{array}$ & $5.03 \pm 0.12$ op & 30 & $1,204 \pm 6.4$ o & 22 & $905 \pm 4.8$ opqr & 28 \\
\hline Sweet Long Slim Red & $4.59 \pm 0.13 \mathrm{pq}$ & 31 & $1,202 \pm 4.5 \mathrm{o}$ & 23 & $1,178 \pm 21.8 \mathrm{gh}$ & 11 \\
\hline Edison & $4.44 \pm 0.01 \mathrm{q}$ & 32 & $925 \pm 2.5 \mathrm{w}$ & 37 & $766 \pm 2.6 \mathrm{~s}$ & 35 \\
\hline Carolina Wonder & $4.44 \pm 0.11 \mathrm{q}$ & 33 & $607 \pm 3.8 \beta$ & 43 & $649 \pm 6.9 \mathrm{u}$ & 37 \\
\hline Yağlık Biber (Bursa) & $4.42 \pm 0.02 \mathrm{q}$ & 34 & $1,324 \pm 6.1 \mathrm{~m}$ & 18 & $921 \pm 5.8$ nop & 26 \\
\hline 333 Biber & $4.17 \pm 0.04 \mathrm{qr}$ & 35 & $1,024 \pm 1.2 \mathrm{st}$ & 30 & $568 \pm 10.3 \mathrm{v}$ & 39 \\
\hline Farya & $3.87 \pm 0.13 \mathrm{rs}$ & 36 & $1,052 \pm 11.3 \mathrm{r}$ & 28 & $561 \pm 6.8 \mathrm{v}$ & 40 \\
\hline Salçalık Biber & $3.86 \pm 0.07 \mathrm{rs}$ & 37 & $956 \pm 8.6 \mathrm{v}$ & 34 & $1,075 \pm 13.1 \mathrm{j}$ & 18 \\
\hline Yağlık Biber & $3.67 \pm 0.17 \mathrm{rst}$ & 38 & $1,118 \pm 9.8 \mathrm{p}$ & 24 & $872 \pm 16.1 \mathrm{r}$ & 31 \\
\hline Kale & $3.53 \pm 0.27 \mathrm{st}$ & 39 & $1,037 \pm 7.7 \mathrm{rs}$ & 29 & $883 \pm 2.5 \mathrm{qr}$ & 30 \\
\hline Fiesta & $3.14 \pm 0.06 \mathrm{tu}$ & 40 & $649 \pm 5.4 \alpha$ & 42 & $885 \pm 3.0 \mathrm{pqr}$ & 29 \\
\hline Salçalık Biber (Bursa) & $2.94 \pm 0.05 \mathrm{uv}$ & 41 & $1,011 \pm 4.3 \mathrm{tu}$ & 32 & $714 \pm 7.6 \mathrm{t}$ & 36 \\
\hline Yalova Yağlık & $2.72 \pm 0.02 \mathrm{uv}$ & 42 & $926 \pm 2.1 \mathrm{w}$ & 36 & $539 \pm 4.6 \mathrm{vw}$ & 41 \\
\hline Yalova Çarliston 341 & $2.57 \pm 0.09 \mathrm{v}$ & 43 & $852 \pm 9.8 \mathrm{y}$ & 39 & $1,024 \pm 2.8 \mathrm{k}$ & 19 \\
\hline
\end{tabular}

${ }^{\mathrm{z}}$ Cultivars are ranked by total antioxidant capacity. Rankings for phenolic and vitamin $\mathrm{C}$ content are also included.

${ }^{y}$ Values followed by different letters are significantly different at $P<0.05$ as determined by Fisher's protected least significant difference.

${ }^{x}$ Vitamin $\mathrm{C}$ content for Variegated Flash could not be determined (ND) because the purple-colored fruit extract prevented detection of color change during titration. 
All of these are Sivri types with the exception of 'Domat Biber', which is a stuffing pepper. Mean antioxidant capacity for all lines was $7.47 \pm 0.59$ (SE) mmol Trolox $/ \mathrm{kg}$. Because many different methods are used to determine total antioxidant capacity of fruits and vegetables, direct comparison of the results of the present study with those of other researchers is difficult. However, using a similar method, Pellegrini et al. (2003) found that green chili peppers had a Trolox-equivalent antioxidant capacity of $7.62 \mathrm{mmol} \cdot \mathrm{kg}^{-1}$, a value that is similar to the mean water-soluble antioxidant capacity $\left(7.47 \mathrm{mmol} \cdot \mathrm{kg}^{-1}\right)$ of the cultivars used in this work.

When peppers were grouped by type, it was clear that some types had significantly higher antioxidant activities (Table 3). Sivri types had the highest mean antioxidant capacity closely followed by Süs types. Dolmalık and Çarliston types had intermediate levels, whereas Salçallk types had the lowest mean level of antioxidant capacity, which was 2.8fold lower than the mean for Sivri types. It must be noted, however, that Salçalik types are usually consumed when they are red. At this stage of maturity, these peppers may have considerable lipophilic antioxidant capacity because of their high carotenoid content. Some types of peppers showed more variation for antioxidant capacity among accessions (Fig. 2). Although only five Çarlistontype cultivars were tested, this type showed the most variation with a 4.9 -fold difference between the cultivars with the highest (Çarliston) and lowest ('Yalova Çarliston 341') activities. Similarly, Dolmalık and Sivri types showed 4.6- and 4.1-fold differences in total antioxidant capacity, respectively. In contrast, Salçalık and Süs pepper types were more uniform having only 1.8and 1.4-fold differences in capacity, respectively.

In comparison with $F_{1}$ hybrids and standard varieties, some Turkish cultivars showed dramatically higher antioxidant activities. For example, 'Çarliston Biber' (Bursa) had at least 2.4-fold greater antioxidant capacity than the non-Turkish Çarliston types (Fig. 2). The three Turkish Süs pepper types also had significantly higher antioxidant activities than the other three Süs cultivars.

Total phenolic content. Total phenolic content in the pepper cultivars ranged from 607 to $2724 \mathrm{mg} \cdot \mathrm{kg}^{-1}$, a 4.5 -fold difference in content (Table 2). This range of phenolic

Table 3. Mean values for antioxidants in pepper cultivars grouped by type and pungency.

\begin{tabular}{lcccc}
\hline Pepper type & $\begin{array}{c}\text { Number of } \\
\text { cultivars }\end{array}$ & $\begin{array}{c}\text { Mean antioxidant } \\
\text { capacity }(\mathrm{mmol} \\
\text { Trolox/kg) } \pm \mathrm{SE}\end{array}$ & $\begin{array}{c}\text { Mean phenolic } \\
\text { content }\left(\mathrm{mg} \cdot \mathrm{kg}^{-1}\right) \pm \mathrm{sE}\end{array}$ & $\begin{array}{c}\text { Mean } \\
\text { vitamin C content } \\
\left(\mathrm{mg} \cdot \mathrm{kg}^{-1}\right) \pm \mathrm{SE}\end{array}$ \\
\hline Sivri & 12 & $10.68 \pm 1.23 \mathrm{a}^{\mathrm{z}}$ & $1,630 \pm 140 \mathrm{a}$ & $1,145 \pm 70.2 \mathrm{a}$ \\
Dolmalık & 14 & $6.21 \pm 0.76 \mathrm{bc}$ & $1,017 \pm 84 \mathrm{~b}$ & $921 \pm 72.8 \mathrm{ab}$ \\
Süs & 6 & $9.15 \pm 0.41 \mathrm{ab}$ & $1,717 \pm 191 \mathrm{a}$ & $1,117 \pm 204 \mathrm{ab}$ \\
Çarliston & 5 & $5.71 \pm 1.79 \mathrm{bc}$ & $1,188 \pm 160 \mathrm{~b}$ & $846 \pm 119 \mathrm{ab}$ \\
Salçalık & 6 & $3.77 \pm 0.36 \mathrm{c}$ & $1,090 \pm 63 \mathrm{~b}$ & $838 \pm 76.0 \mathrm{~b}$ \\
\hline Hot & 15 & $8.64 \pm 0.77 \mathrm{a}$ & $1,600 \pm 110 \mathrm{a}$ & $1,044 \pm 88 \mathrm{a}$ \\
Sweet & 28 & $6.84 \pm 0.80 \mathrm{a}$ & $1,163 \pm 81 \mathrm{~b}$ & $962 \pm 55 \mathrm{a}$ \\
\hline
\end{tabular}

${ }^{\mathrm{z}}$ Within each column and grouping, values followed by different letters are significantly different at $P<$ 0.05 as determined by Fisher's protected least significant difference.

content was similar to that reported by other researchers (Antonious et al., 2006; Chassy et al., 2006). The five cultivars with the highest phenolic content included four Turkish cultivars [Ege-91, Finli Biber, Arnavut Biber (sivri), and Menderes] and one nonTurkish cultivar (Variegated Flash). All of these peppers except for 'Variegated Flash' are Sivri types. 'Variegated Flash' is a Süs type and was one of the two cultivars for which the fruit extract contained seeds. It was reported that seeds are a source of phenolic compounds in pepper (Velioglu et al., 1998). Therefore, the high phenolic content of 'Variegated Flash' may be attributable to its seeds. However, the other cultivar that had seeds in its extract ('Arnavut Biber') did not have especially high phenolic content. Mean phenolic content for all lines was $1316 \pm 72$ (SE) $\mathrm{mg} \cdot \mathrm{kg}^{-1}$. Süs and Sivri types had significantly higher mean phenolic content than the other three types of pepper (Table 3 ). Dolmalık and Sivri types showed the most variation in phenolic content with $\approx 3$-fold variation in these cultivars (Fig. 3). The least variation was seen in Salçalık types.

As with antioxidant capacity, some Turkish lines had significantly higher phenolic content than the non-Turkish cultivars. For example, the Dolmalik types, 'Domat' and 'Ac1 Biber' (Gaziantep), had significantly higher phenolic content than 'Yolo Wonder' and 'Apollo $F_{1}$ ' (Fig. 3). 'Çarliston Biber' also had significantly higher phenolic content than the $F_{1}$ hybrid 'Raspires' and cultivar 'Farya'.

The total phenolic content of pepper as measured by the Folin-Ciocalteu assay encompasses a wide diversity of compounds, including simple phenols, phenolic acids, flavonoids, lignin precursors, capsaicinoids, and reducing sugars (Howard et al., 2000). Individual flavonoids, including luteolin, quercetin, and kaempferol (Chassy et al., 2006; Howard et al., 2000), were measured in pepper and some recent studies provided detailed qualitative and quantitative characterization of pepper phenolic compounds (Marin et al., 2004; Materska and Perucka, 2005).

Vitamin C content. Vitamin $\mathrm{C}$ content in the peppers ranged from 522 to $1631 \mathrm{mg} \cdot \mathrm{kg}^{-1}$, a 3.1-fold difference in content (Table 2). This range of vitamin $\mathrm{C}$ content was similar to that seen in other studies (Antonious et al., 2006; Chassy et al., 2006; Deepa et al., 2006; Howard et al., 2000; Marin et al., 2004). A notable exception is the work of Guil-Guerrero et al. (2006), which reported vitamin C contents of 100 to $380 \mathrm{mg} / 100 \mathrm{~g}$ for 10 pepper cultivars grown in Spain. The five cultivars with highest vitamin $\mathrm{C}$ content included three Turkish and two non-Turkish cultivars. These lines were 'Arnavut Biber', 'Ege-91', 'Yolo Wonder', 'Yalova Tatlı Sivri Biber', and 'Cherry Pick' with vitamin C content averaging $990 \pm 47$ (SE) $\mathrm{mg} \cdot \mathrm{kg}^{-1}$. Interestingly, 100 -g serving sizes of all but four of the cultivars assayed in this work supply $100 \%$ of the daily Recommended Dietary Allowance of vitamin C, $60 \mathrm{mg}$ (Table 2). Similarly, the majority of the cultivars $(67 \%)$ meet the more recently devised Dietary Reference Intake for vitamin $\mathrm{C}$, which averages between 75 and $90 \mathrm{mg}$ for adult women and men, respectively (International Food Information Council, 2002). Sivri and Süs types had the highest mean vitamin C content (Table 3). Dolmalık types showed the most variation in vitamin $\mathrm{C}$ content with a 2.9-fold range in concentration (Fig. 4). The other pepper types had 1.5- to 2.0-fold variation in vitamin $\mathrm{C}$ content.

Turkish Sivri, Süs, and Çarliston-type pepper lines had significantly higher vitamin $\mathrm{C}$ content than non-Turkish cultivars. However, 'Yolo Wonder', a non-Turkish cultivar, had the highest vitamin $\mathrm{C}$ content of the Dolmalık types (Fig. 4).

Relationship between pungency and antioxidant capacity. To determine the relationship between pepper pungency and antioxidant capacity, mean values for hot and sweet types were compared (Table 3). Hot types had higher total antioxidant capacity, phenolic content, and vitamin $\mathrm{C}$ content; however, the difference between means was only statistically significant $(P<0.05)$ for phenolic content (Table 3 ). This was not unexpected because capsaicin, the compound that gives peppers their pungency, is a capsaicinoid, a type of phenolic compound (Estrada et al., 2002).

Correlation between antioxidant parameters. All three antioxidant parameters showed statistically significant $(P<0.05)$ correlations between each other. The strongest correlation was between total antioxidant capacity and phenolic content $(r=0.71)$. There were also significant positive but weaker correlations between total antioxidant capacity and vitamin $\mathrm{C}$ content $(r=0.51)$ and between vitamin $\mathrm{C}$ and phenolic content $(r=0.31)$. Other researchers observed significant correlations between total antioxidant capacity and its components. Significant positive correlations were seen between total antioxidant capacity and phenolic content in pepper (Deepa et al., 2007), tomato (Hanson et al., 2004), eggplant (Hanson et al., 2006), cranberry (Wang and Stretch, 2001), and blueberry (Howard et al., 2003). Antonious et al. (2006) reported a much stronger correlation between phenolic and vitamin $\mathrm{C}$ content $(r=0.97)$ than that reported in the present study. The correlations between the different antioxidant components were also apparent when the pepper cultivars were ranked by the value for each measured parameter (Table 2). Thus, 'Ege-91', 


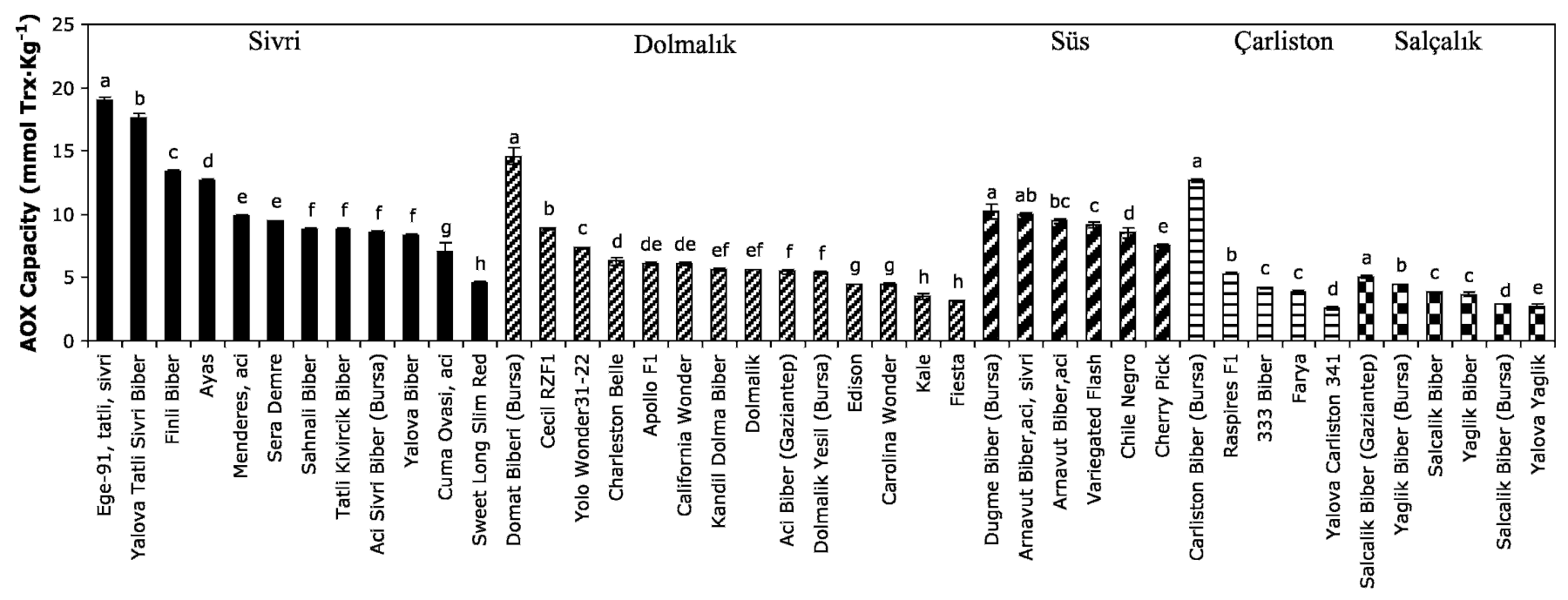

CULTIVARS

Fig. 2. Antioxidant capacities of the pepper cultivars grouped by type. Within each type, columns labeled with different letters are significantly different at $P<0.05$ as determined by Fisher's protected least significant difference.

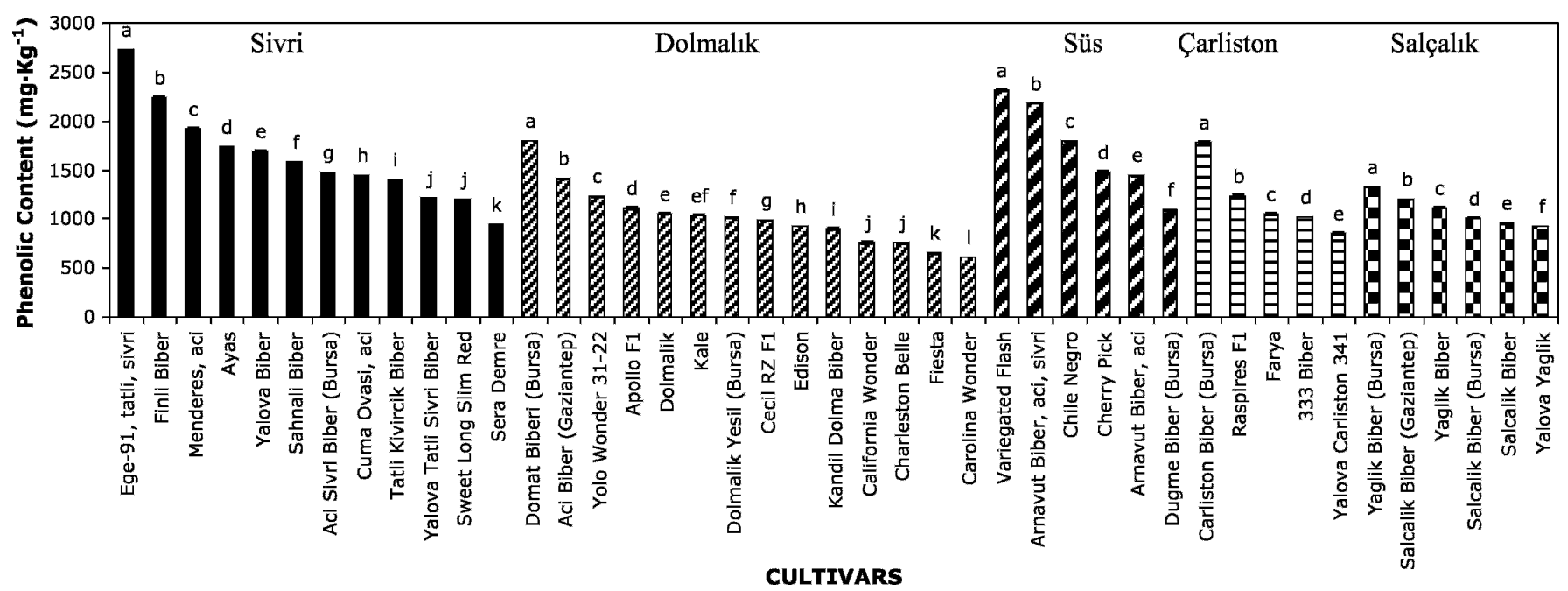

Fig. 3. Total phenolic content of the pepper cultivars grouped by type. Within each type, columns labeled with different letters are significantly different at $P<0.05$ as determined by Fisher's protected least significant difference.

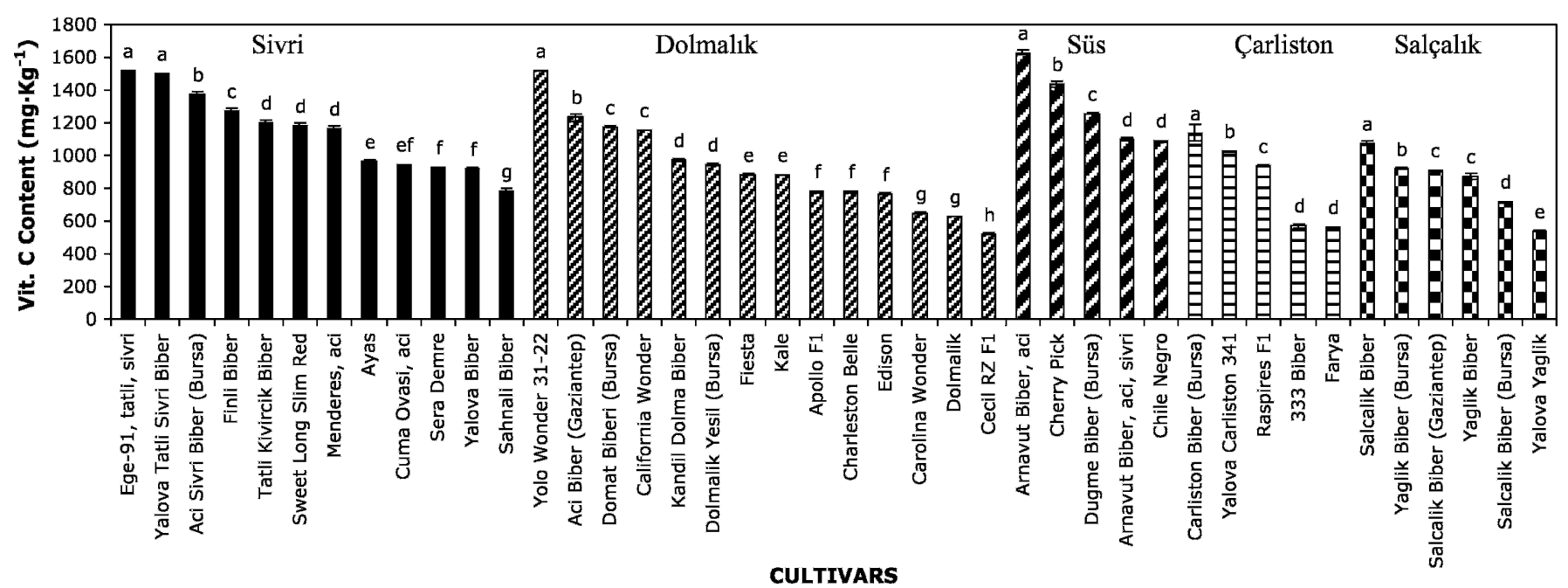

Fig. 4. Vitamin C content of the pepper cultivars grouped by type. Within each type, columns labeled with different letters are significantly different at $P<0.05$ as determined by Fisher's protected least significant difference. 
which ranked first for total antioxidant capacity, also ranked first for phenolic content and second for vitamin $\mathrm{C}$ content. The correlations were especially obvious when cultivars were ranked within each type (Sivri, Dolmallk, and so on, Figs. 2-4). Within their type categories, 'Ege-91' (Sivri) and 'Çarliston Biber' ranked first for all three parameters. 'Domat Biberi' ranked first for total antioxidant capacity and phenolic content and third for vitamin $\mathrm{C}$ content in the Dolmalık types. Similarly, 'Salçalık Biber' from Gaziantep ranked first, second, and third for total antioxidant capacity, phenolic content, and vitamin $\mathrm{C}$ content, respectively. Such correlations were expected because the total antioxidant capacity assay measured the activity of all water-soluble antioxidants, including phenolics and vitamin $\mathrm{C}$.

\section{Conclusions}

The genetic diversity present in Turkish pepper germplasm for total water-soluble antioxidant capacity, phenolic content, and vitamin $\mathrm{C}$ content can be exploited for the development of populations for identification and genetic mapping of the loci controlling these traits in pepper and for the breeding of cultivars with improved antioxidant capacity. 'Ege-91' was the best cultivar for all three antioxidant parameters and is a good candidate for improvement of antioxidants in Turkish peppers, especially in Sivri types. Similarly, 'Domat Biber' would be a good candidate for improvement of total antioxidant capacity and phenolic content of Dolmalık-type peppers. Development and consumption of pepper cultivars with high antioxidant activity may help decrease the incidence of certain types of diseases in humans. It will also be interesting to see if these improved cultivars have increased tolerance to biotic and abiotic stress.

\section{Literature Cited}

Antonious, G.F., T.S. Kochhar, R.L. Jarret, and J.C. Snyder. 2006. Antioxidants in hot pepper: Variation among accessions. J. Environ. Sci. Heal. B 41:1237-1243.

Augustin, J. 1994. Vitamin analysis, p. 249-260. In: Nielsen, S.S. (ed.). Introduction to the chemical analysis of food. Jones \& Bartlett, Boston, MA.

Bloch, A. and C.A. Thomson. 1995. Position of the American Dietetic Association: Phytochemicals and functional foods. J. Amer. Diet. Assoc. 95:493-496.

Cao, G., E. Sofic, and R.L. Prior. 1996. Antioxidant capacity of tea and common vegetables. J. Agr. Food Chem. 44:3426-3431.

Chassy, A.W., L. Bui, E.N.C. Renaud, M. Van Horn, and A.E. Mitchell. 2006. Three-year comparison of the content of antioxidant microconstituents and several quality characteristics in organic and conventionally man- aged tomatoes and bell peppers. J. Agr. Food Chem. 54:8244-8252.

Chu, Y.-F., J. Sun, X. Wu, and R.H. Liu. 2002. Antioxidant and antiproliferative activities of common vegetables. J. Agr. Food Chem. 50:6910-6916.

Davey, M.W., M. van Montagu, D. Inze, M. Sanmartin, A. Kanellis, N. Smirnoff, I.J.J. Benzie, J.J. Strain, D. Favell, and J. Fletcher. 2000. Plant L-ascorbic acid: Chemistry, function, metabolism, bioavailability and effects of processing. J. Sci. Food Agr. 80:825-860.

Deepa, N., C. Kaur, B. George, B. Singh, and H.C. Kapoor. 2007. Antioxidant constituents in some sweet pepper (Capsicum annuum L.) genotypes during maturity. LWT-Food Sci. Technol. 40:121-129.

Deepa, N., C. Kaur, B. Singh, and H.C. Kapoor. 2006. Antioxidant activity in some red sweet pepper cultivars. J. Food Compos. Anal. 19:572-578.

Estrada, B., M.A. Bernal, J. Diaz, F. Pomar, and F. Merino. 2002. Capsaicinoids in vegetative organs of Capsicum annuum L. in relation to fruiting. J. Agr. Food Chem. 50:1188-1191.

Ferrari, C.K.B. and E.A.F.S. Torres. 2003. Biochemical pharmacology of functional foods and prevention of chronic diseases of aging. Biomed. Pharmacother. 57:251-260.

Food and Agriculture Organization of the United Nations. 2005. Agricultural data FAOSTAT. 1 May 2007. <http://faostat.fao.org/site/340/ default.aspx $>$.

Gnayfeed, M.H., H.G. Daood, P.A. Biacs, and C.F Alcaraz. 2001. Content of bioactive compounds in pungent spice red pepper (paprika) as affected by ripening and genotype. J. Sci. Food Agr. 81:1580-1585.

Guil-Guerrero, J.L., C. Martinez-Guirado, M. Rebolloso-Fuentes, and A. Carrique-Perez. 2006. Nutrient composition and antioxidant activity of 10 pepper (Capsicum annuиm L.) varieties. Eur. Food Res. Technol. 224:1-9.

Halliwell, B. 2006. Reactive species and antioxidants. Redox biology is a fundamental theme of aerobic life. Plant Physiol. 141:312-322.

Halvorsen, B.L., K. Holte, M.C.W. Myhrstad, I. Barikmo, E. Hvattum, S.F. Remberg, A.-B. Wold, K. Haffner, H. Baugerod, L.F. Andersen, J.O. Moskaug, D.R. Jacobs, and R. Blomhoff. 2002. A systematic screening of total antioxidants in dietary plants. J. Nutr. 132:461-471.

Hanson, P.M., R.-Y. Yang, S.C.S. Tsou, D. Ledesma, L. Engle, and T.-C. Lee. 2006. Diversity in eggplant for superoxide scavenging activity, total phenolics and ascorbic acid. J. Food Comp. Anal. 19:594-600.

Hanson, P.M., R.-Y. Yang, J. Wu, J.-T. Chen, D. Ledesma, and S.C.S. Tsou. 2004. Variation for antioxidant activity and antioxidants in tomato. J. Amer. Soc. Hort. Sci. 129:704-711.

Howard, L.R., J.R. Clark, and C. Brownmiller. 2003. Antioxidant capacity and phenolic content in blueberries as affected by genotype and growing season. J. Sci. Food Agr. 83:12381247.

Howard, L.R., S.T. Talcott, C.H. Brenes, and B. Villalon. 2000. Changes in phytochemical and antioxidant activity of selected pepper cultivars (Capsicum species) as influenced by maturity. J. Agr. Food Chem. 48:1713-1720.

International Food Information Council. 2002. Dietary reference intakes: An update. 1 May
2007. <http://ific.org/publications/other/ driupdateom.cfm?renderforprint $=1>$.

Marin, A., F. Ferreres, F.A. Tomas-Barberan, and M.I. Gil. 2004. Characterization and quantitation of antioxidant constituents of sweet peppers (Capsicum annuum L.). J. Agr. Food Chem. 52:3861-3869.

Materska, M. and I. Perucka. 2005. Antioxidant activity of the main phenolic compounds isolated from hot pepper fruit (Capsicum annuum L.). J. Agr. Food Chem. 53:1750-1756.

Navarro, J.M., P. Flores, C. Garrido, and V. Martinez. 2006. Changes in the contents of antioxidant compounds in pepper fruits at different ripening stages, as affected by salinity. Food Chem. 96:66-73.

Ou, B., D. Huang, M. Hampsch-Woodill, J.A. Flanagan, and E.K. Deemer. 2002. Analysis of antioxidant activities of common vegetables employing oxygen radical absorbance capacity (ORAC) and ferric reducing antioxidant power (FRAP) assays: A comparative study. J. Agr. Food Chem. 50:3122-3128.

Pellegrini, N., M. Serafini, B. Colombi, D. Del Rio, S. Salvatore, M. Bianchi, and F. Brighenti. 2003. Total antioxidant capacity of plant foods, beverages and oils consumed in Italy assessed by three different in vitro assays. J. Nutr. 133: 2812-2819.

Percival, M. 1998. Antioxidants. Clinical nutrition insights. 1:1-5. 1 May 2007. <http://acudoc. com/Antioxidants.PDF>.

Podsedek, A. 2007. Natural antioxidants and antioxidant capacity of Brassica vegetables: A review. LWT-Food Sci. Technol. 40:1-11.

Re, R., N. Pellegrini, A. Proteggente, A. Pannala, M. Yang, and C. Rice-Evans. 1999. Antioxidant activity applying an improved ABTS radical cation decolorization assay. Free Radical Bio. Med. 26:1231-1237.

Sakihama, Y., M.F. Cohen, S.C. Grace, and H. Yamasaki. 2002. Plant phenolic antioxidant and prooxidant activities: Phenolics-induced oxidative damage mediated by metals in plants. Toxicology 177:67-80.

Singleton, V.L. and J.A. Rossi, Jr. 1965. Colorimetry of total phenolics with phosphomolybdic phosphotungstic acid reagents. Amer. J. Enol. Viticult. 16:144-158.

Slater, A., N.W. Scott, and M. Fowler. 2003. Plant biotechnology: The genetic manipulation of plants. Oxford Univ. Press, Oxford, UK.

Surh, Y.J. and S.K. Seoul. 2002. Anti-tumor promoting potential of selected spice ingredients with oxidative and anti-inflammatory activities. Food Chem. Toxicol. 40:1091-1097.

USDA Nutrient Data Laboratory. 2007. USDA national nutrient database for standard reference. 1 May 2007. <http://www.nal.usda.gov/ fnic/foodcomp/search>.

Velioglu, Y.S., G. Mazza, L. Gao, and B.D. Oomah. 1998. Antioxidant activity and total phenolics in selected fruits, vegetables and grain products. J. Agr. Food Chem. 46:4113-4117.

Wang, S.Y. and A.W. Stretch. 2001. Antioxidant capacity in cranberry is influenced by cultivar and storage temperature. J. Agr. Food Chem. 49:969-997.

Wu, X., G.R. Beecher, J.M. Holden, D.B. Haytowitz, S.E. Gebhardt, and R.L. Prior. 2004. Lipophilic and hydrophilic antioxidant capacities of common foods in the United States. J. Agr. Food Chem. 52:4026-4037. 